\title{
Az idegkímélő mütéti technika jelentősége a mélyen infiltráló endometriosis sebészetében
}

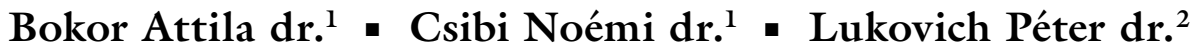 \\ Brubel Réka dr. ${ }^{1}$ - Joó József Gábor dr. ${ }^{1}$ - Rigó János dr. ${ }^{1}$
}

Semmelweis Egyetem, Általános Orvostudományi Kar,

${ }^{1}$ I. Szülészeti és Nőgyógyászati Klinika, ${ }^{2}$ I. Sebészeti Klinika, Budapest

\begin{abstract}
Bevezetés: A mélyen infiltráló endometriosis kezelésében az elváltozások hagyományos sebészi eltávolítása súlyos szövődményekkel járhat. Célkitüzés: Idegkímélő, illetve hagyományos technikával végzett mútétek összehasonlítása, az egyes szövődmények előfordulási gyakoriságának ismertetése mélyen infiltráló endometriosissal foglalkozó munkacsoportok mútéti eredményeinek összefoglalásával. Módszer: A szerzők retrospektív elemzést végeztek a 2004. március 31. és 2015. március 31. között megjelent tudományos közlemények felhasználásával. A keresést a http://www. pubmed.org adatbázisban végezték az „endometriosis”, „deep infiltrating,” „nerve-sparing, surgery” (endometriosis, mélyen infiltráló, idegkímélő, sebészet) keresőszavak kombinációjának alkalmazásával. Eredmények: Mélyen infiltráló endometriosis kapcsán végzett, nem idegkímélő beavatkozásokat követően 19,1-38,5\%-ban jelentkezhet átmeneti húgyhólyag-diszfunkció, míg idegkímélő mútéti technika alkalmazását követően a betegek 0,61-33,3\%-ában fordulhat elő. Nem idegkíméló technika alkalmazását követően a betegek átlagosan 121,1 napig, idegkímélő mútéteket követôen 7-39,8 napig szorultak önkatéterezésre. Krónikus húgyhólyag-diszfunkció mélyen infiltráló endometriosis miatt végzett idegkímélő mútéteket követően nem fordult elő. Köpetkeztetések: Az idegkímélő technikák alkalmazása a betegek életminőségének jelentős javulását eredményezi, mivel panaszaik kezelése mellett alacsonyabb posztoperatív szövődményrátával társul. Orv. Hetil., 2015, 156(48), 1960-1965.
\end{abstract}

Kulcsszavak: nőgyógyászat, mủtét, endometriosis, neurogén húgyhólyag-diszfunkció

\section{Importance of nerve-sparing surgical technique in the treatment of deep infiltrating endometriosis}

Introduction: Traditional surgeries performed in cases of deep infiltrating endometriosis lead to impaired quality of life. Aim: To summarize the postoperative outcome and to compare the rate of postoperative complications after different therapeutic approaches applied in deep infiltrating endometriosis. Method: The authors analized the articles published between March 31, 2004 and March 31, 2015, in the database www.pubmed.org using the following keywords: endometriosis, deep infiltrating, nerve sparing, surgery. Results: Non-nerve sparing surgery resulted in temporary urinary dysfunction in $19.1-38.5 \%$ of patients, while it occurred in $0.61-33.3 \%$ of patients after nervesparing surgery. Non-nerve sparing surgical technique resulted in an avarage of 121 days of need for self-catheretisation. When nerve-sparing surgeries were performed the duration of self-catheterisation varied between 7 to 39.8 days. After nerve sparing surgeries, permanent bladder dysfunction was not detected in any case. Conclusions: Because of the successful treatment of the patients symptoms and the lower postoperative complication rate, nerve-sparing surgical technique leads to a significant improvement of the quality of life.

Keywords: laparoscopic surgery, endometriosis, neurogenic bladder dysfunction

Bokor, A., Csibi, N., Lukovich, P., Brubel, R., Joó, J. G., Rigó, J. [Importance of nerve-sparing surgical technique in the treatment of deep infiltrating endometriosis]. Orv. Hetil., 2015, 156(48), 1960-1965.

(Beérkezett: 2015. augusztus 31.; elfogadva: 2015. október 1.) 


\section{Rövidítések}

BFLUTS $=$ Bristol Female Lower Urinary Tract Symptoms; DIE $=($ deep infiltrating endometriosis $)$ mélyen infiltráló endometriosis; IPSS = International Prostate Score System; n. a. = nem áll rendelkezésre adat

$\mathrm{Az}$ endometriosis krónikus, ösztrogéndependens nőgyógyászati betegség, amely az endometriumhoz hasonló mirigy- és stromaszövet proliferációjával jár a méh üregén kívül [1]. Előfordulási gyakorisága a reproduktív korú női populációban 6-10\% közötti [1]. Legsúlyosabb megjelenési formája a mélyen infiltráló endometriosis (deep infiltrating endometriosis - DIE), amely esetén a laesio a peritoneum szintjétól $5 \mathrm{~mm}$-es vagy azt meghaladó mélységbe terjed [2,3].

A mélyen infiltráló laesiók elsősorban a kismedence hátsó részén, a sacrouterin szalagokon, a spatium rectovaginaléban, a Douglas-üregben, valamint a hüvely hátsó és a rectum mellső falán találhatók. Gastrointestinalis laesiók az esetek 5,3-12\%-ában jelennek meg [1, 4, 5, $6,7]$. A DIE érintheti a kismedence elülső régióját is, jelentkezhet a plica vesicouterinán és infiltrálhatja a húgyhólyag izomzatát. Érintheti a kismedence lateralis falát, ezáltal veszélyeztetheti az ott elhelyezkedő szomatikus idegek lefutását $[3,4,8,9]$.

A mélyen infiltráló endometriosis kedvezőtlenül befolyásolja a betegek életminőségét. Az irodalmi adatok szerint gazdasági jelentőségét az egészségügyi kiadások mellett elsősorban a megromlott, csökkent munkaképesség adja [10]. Legfontosabb tünetei a krónikus kismedencei fájdalom, fájdalmas menstruáció, a szexuális élet, illetve a vizelet- és a székletürítés kapcsán jelentkező fájdalom. A fájdalom mellett az endometriosis gyakran meddőséggel társul $[1,2]$. Ezenkívül a DIE - lokalizációtól függően különböző valószínûséggel - további vizeletürítési panaszokat és akár „néma” urodinámiás eltéréseket is okozhat [11]. Elsősorban colorectalis érintettség esetén számolhatunk sürgető vizelési inger, gyakori vizeletürítés, húgyhólyagizomgörcsök, akaratlan vizeletvesztés, illetve húgyhólyag-hypaesthesia megjelenésével. A panaszok hátterében a plexus hypogastricus inferior rectum anterolateralis falához igen közeli elhelyezkedése és így a rostok endometriosis általi érintettsége állhat $[11,12]$.

A DIE kezelése elsősorban sebészi, és a látható elváltozások eltávolítását foglalja magában. A radikális kismedencei beavatkozások azonban emelkedett perioperatív morbiditással járnak $[7,13,14,15,16,17]$. A rectovaginalis spatium, illetve a sacrouterin szalagok endometriosisának bélreszekcióval vagy a nélkül történő eltávolítása során sérülhet a kismedencei autonóm idegrendszer, amelynek következménye constipatio és vizeletürítési képtelenség lehet; utóbbi időnként az élet végéig tartó önkatéterezéshez vezethet. A DIE miatti colorectalis beavatkozások 17\%-ában figyeltek meg az életminőségre tartósan kiható húgyúti szövődményeket [18].
Több munkacsoport vizsgálta, hogy a korai méhnyakrák kapcsán végzett mútétekhez hasonlóan a mélyen infiltráló endometriosis esetében is kivitelezhető-e az idegkímélő mütéti technika és ez a szövődmények csökkenését eredményezi-e.

Az idegkímélő mütéti technikát gyakorló munkacsoportok intra- és posztoperatív eredményeit dolgoztuk fel. Célunk a nem idegkímélő, illetve az idegkímélő beavatkozásokhoz társuló posztoperatív szövődmények gyakoriságának összehasonlítása volt.

\section{Módszer}

Retrospektív elemzést végeztünk irodalomkutatással. A mélyen infiltráló endometriosis kezelésében idegkímélő mütéti technikát alkalmazó munkacsoportok posztoperatív eredményeivel foglalkozó olyan angol nyelvü közleményeket kerestünk, amelyek 2004. március 31. és 2015. március 31. között jelentek meg. Ismertetjük továbbá saját, mélyen infiltráló endometriosissal foglalkozó laparoszkópos munkacsoportunk eredményeit is, amelyeket 2014-ben publikáltunk [19]. A PubMed elektronikus adatbázisban (http://www.pubmed.org) megtalálható publikációk közül az „endometriosis”, „deep infiltrating”, „nerve-sparing” és „surgery” (endometriosis, mélyen infiltráló, idegkímélő, sebészet) keresőszavak kombinációjával lehívható tanulmányokat dolgoztuk fel.

Vizsgáltuk a colorectalis, az urinalis és a szexuális életet befolyásoló szövődmények előfordulási gyakoriságát az idegkíméletre törekvő, illetve a klasszikus, radikális mútéti beavatkozásokat követően. A posztoperatív húgyhólyag-diszfunkciók incidenciája mellett összehasonlítottuk azok spontán gyógyhajlamát, a fiziológiás húgyhólyagmúködés visszanyeréséhez szükséges időtartamot különböző műtéti technikák alkalmazását követően. A betegek életminőségét validált kérdőíves vizsgálatok eredményei alapján is jellemeztük.

A feldolgozott közleményeket a betegek életkora, az ismertetett mútéti beavatkozások időtartama, a társuló vérvesztés, a posztoperatív transzfúzió szükségessége és a mütét utáni átlagos kórházi tartózkodás alapján is elemeztük.

\section{Eredmények}

Irodalmi áttekintésünk során nyolc, idegkímélő mütéti beavatkozások posztoperatív eredményeit ismertető tanulmányt találtunk. Hat eredeti közlemény (négy prospektív és két prospektív randomizált) és két összefoglaló tanulmány eredményeit dolgoztuk fel. Az elvégzett beavatkozások általános jellemzőit és a húgyhólyag-diszfunkció, illetve az önkatéterezés gyakoriságát az áttekintett tanulmányokban az 1 . és 2. táblázat foglalja össze.

A feldolgozott közleményekben a mütéti javallatot mélyen infiltráló endometriosis, illetve Possover és mtsainak közleményében az esetek egy részében DIE, a má- 
1. táblázat |Az idegkímélő műtéti beavatkozások perioperatív jellemzői

\begin{tabular}{|c|c|c|c|c|c|c|}
\hline Szerzők & Esetszám & $\begin{array}{l}\text { Betegek életkora } \\
\text { (év - medián érték: } \\
\text { minimum-maximum) }\end{array}$ & $\begin{array}{l}\text { Mütéti idő } \\
\text { (min - medián } \\
\text { érték: minimum- } \\
\text { maximum) }\end{array}$ & $\begin{array}{l}\text { Átlagos vérvesztés } \\
\text { (ml - medián érték) }\end{array}$ & $\begin{array}{l}\text { Transzfúzióra } \\
\text { szoruló betegek } \\
\text { száma }\end{array}$ & $\begin{array}{l}\text { Átlagos kórházi } \\
\text { tartózkodás } \\
\text { (nap - medián érték: } \\
\text { minimum-maximum) }\end{array}$ \\
\hline Volpi és mtsai [20] & 24 & $\begin{array}{l}31,5 \\
(23-42)\end{array}$ & $\begin{array}{l}110 \\
(50-230)\end{array}$ & n. a. & 2 & $3(1-9)$ \\
\hline Possover és mtsai [21] & 91 & $\begin{array}{l}26,9 \\
(18-45)\end{array}$ & $\begin{array}{l}196 \\
(153-312)\end{array}$ & n. a. & 2 & $9,2(8-14)$ \\
\hline Kavallaris és mtsai [2] & 16 & $\begin{array}{l}32 \\
(24-42)\end{array}$ & 82 & 250 & n. a. & $7(5-14)$ \\
\hline Ceccaroni és mtsai [5] & 61 & $\begin{array}{l}34 \\
(24-46)\end{array}$ & 301,5 & 354,9 & n. a. & n. a. \\
\hline Bokor és mtsai [19] & 50 & $\begin{array}{l}31 \\
(27-45)\end{array}$ & $\begin{array}{l}185 \\
(85-470)\end{array}$ & n. a. & 5 & n. a. \\
\hline
\end{tabular}

sikban korai méhnyakrák képezte [2, 4, 20, 21]. Utóbbi tanulmány esetében csak a mélyen infiltráló endometriosis kapcsán elvégzett mütétek jellemzőit és eredményeit értékeltük.

Az operált betegek száma 16-91 között változott a feldolgozott közleményekben. Az egyes tanulmányokban a betegek életkorának medián értéke 26,9 és 34 év között volt. A mütétek időtartama a különböző munkacsoportok eredményei alapján széles határok között váltakozott. Az összehasonlított tanulmányokban az átlagos mütéti időtartam 82 perc és 301,5 perc között volt [2,4] (1. táblázat).

Két tanulmány számolt be a mütét alatti átlagos vérvesztésről, három a posztoperatív transzfúzió szükségességéről. Az intraoperatív vérvesztés medián értéke 250 és $354,9 \mathrm{ml}$ volt a két vizsgált tanulmányban. Mútét utáni transzfúzióra Volpi és munkatársainak tanulmányában két esetben $(8,3 \%)$, Possover és munkatársainak DIE miatt végzett mütétei kapcsán szintén két esetben $(2,2 \%)$, Bokor és munkatársainak tanulmányában öt esetben (10\%) volt szükség [2, 20, 21] (1. táblázat).

A kórházi bennfekvés időtartamának medián értéke 3-9,2 nap között váltakozott $[2,20,21]$ (1. táblázat).

Possover és munkatársainak idegkímélő műtéti eredményeket feldolgozó vizsgálatában tartós önkatéterezésre az operált betegek 0,61\%-ában (csak a korai méhnyakrák miatt végzett mütétet követően) volt szükség [21]. Mélyen infiltráló endometriosis miatt végzett idegkímélő mütéti beavatkozások kapcsán tartós húgyhólyag-diszfunkciót nem észleltek, a tehermentesítő, suprapubicus katéter kétnapos hólyagtornát követően minden beteg esetén eltávolítható volt [21] (2. táblázat).

Kavallaris és mtsai 16, idegkímélő technikával operált betegükből 13 esetében már az első posztoperatív napon sikeres spontán vizeletürítésről számoltak be. Önkatéterezés csupán a húgyhólyag-, illetve az ureterreszekción átesett betegekben vált átmenetileg szükségessé. Az önkatéterezés átlagos időtartama 8 nap volt [2].
Volpi és mtsainak tapasztalatai szerint mindkét oldali sacrouterinszalagot érintő DIE esetén, amennyiben a mindkét oldali plexus hypogastricus inferior reszekció elkerülhetetlen volt, a betegek 90\%-a átmenetileg önkatéterezővé vált. Egyoldali plexus hypogastricus inferior reszekció esetén a betegek 71,4\%-ában lépett fel átmeneti húgyhólyag-diszfunkció. Összességében az önkatéterezés átlagos időtartama 18 nap volt. Szignifikáns összefüggést észleltek az első posztoperatív vizeletürítést követő ultrahangos vizeletresiduum-becslés értéke és az önkatéterezés előfordulási gyakorisága között [20].

Ceccaroni és mtsai prospektív, randomizált tanulmányukban, idegkímélő beavatkozásokat követően, szignifikánsan alacsonyabb kismedencei neurogén diszfunk-

2. táblázat $\mid$ Az önkatéterezés gyakorisága idegkímélő mútéti technikával operált betegek körében

\begin{tabular}{llll}
\hline Szerzók & Esetszám & $\begin{array}{l}\text { Önkatéterezésre } \\
\text { szoruló betegek } \\
\text { száma }\end{array}$ & $\begin{array}{l}\text { Önkatéterezés } \\
\text { idótartamának } \\
\text { átlagértéke (nap) }\end{array}$ \\
\hline $\begin{array}{l}\text { Volpi és mtsai } \\
{[20]}\end{array}$ & 24 & $7(29,2 \%)$ & 18 \\
$\begin{array}{l}\text { Possover és } \\
\text { mtsai [21] }\end{array}$ & 91 & $0^{*}$ & - \\
$\begin{array}{l}\text { Kavallaris és } \\
\text { mtsai [2] }\end{array}$ & 16 & $3(18,5 \%)^{* *}$ & $\mathrm{n}$. a. \\
$\begin{array}{l}\text { Ceccaroni és } \\
\text { mtsai [5] }\end{array}$ & 61 & n. a. & 39,8 \\
$\begin{array}{l}\text { Bokor és } \\
\text { mtsai [19] }\end{array}$ & 50 & $6(12 \%)$ & $\leq 7^{* * *}$ \\
\hline
\end{tabular}

*Krónikus hólyagatónia előfordulási gyakorisága méhnyakrák miatt operált betegekben $0,61 \%$ volt. DIE miatt végzett műtétek esetén egy esetet sem dokumentáltak.

** Állandó katéter viselése 7-9 napig csupán ureter-, illetve hólyagreszekció esetén fordult elő. A többi operált beteg esetén a katéter eltávolítását követő 1 . napon szignifikáns residuum nélkül sikeres volt a vizeletürítés.

***A húgyhólyag-diszfunkció maximum 7 nap alatt maradéktalanul gyógyult. 
3. táblázat $\mid$ Kismedencei beidegzés posztoperatív zavarai szegmentális bélreszekciót követően nem idegkímélő (A), illetve idegkíméló (B) beavatkozásokat követően Ceccaroni és munkatársainak mútéti eredményei alapján

\begin{tabular}{llll}
\hline & $\mathrm{A}(\mathrm{n}=65)$ & $\mathrm{B}(\mathrm{n}=61)$ & $\mathrm{p}$ \\
\hline $\begin{array}{l}\text { Önkatéterezés } \\
\left.\text { (napok - átlag }{ }_{ \pm} \mathrm{SD}\right)\end{array}$ & $121,1(67,9)$ & $39,8(29,5)$ & $<0,001$ \\
$\begin{array}{l}\text { Neuromodulációra } \\
\text { javasoltak száma }\end{array}$ & $10(15,4 \%)$ & $1(1,6 \%)$ & $<0,5$ \\
\hline
\end{tabular}

cióról számoltak be, mint a nem idegkímélő mütétek után (3. táblázat). Idegkímélő mütéti technika alkalmazása esetén szignifikánsan alacsonyabb volt az önkatéterezés időtartama, mint a klasszikus mútéteket követően. A húgyhólyagfunkció spontán visszanyerése előbbi esetben átlagosan 39,8, míg a klasszikus, radikális mútéteket követően 121,1 napot vett igénybe (2. táblázat). Az önkatéterező betegek utánkövetése során szignifikánsan ritkábban fordult elő a húgyhólyagfunkció spontán javulása nem idegkímélő mútéteket követően, mint az idegkímélő mütétek után. A betegek gyakrabban számoltak be csökkent szexuális vágyról, orgazmuszavarról vagy akár az orgazmus teljes hiányáról, továbbá krónikus constipatióról a klasszikus mútétek után, mint idegkímélő beavatkozásokat követően. Ugyanakkor a korai posztoperatív szövődmények arányában, a fájdalmi tünetek javulásában és a recidívák előfordulási gyakoriságában nem volt szignifikáns különbség a két mütéti technika között [4].

Ballester és mtsai prospektív randomizált tanulmányukban összességében az esetek 29\%-ában észleltek posztoperatív nehéz vizelést, 11\%-ában sürgető vizelési ingert, 14\%-ában stressz-, 3\%-ában pedig spontán inkontinenciát. Idegkímélő mütéten átesett betegeik esetén is az esetek 19\%-ában jelentkezett dysuria. Egyértelmú idegreszekciót követôen vizeletretenció az érintett betegek $88 \%$-ában jelent meg. Betegeik posztoperatív életminőségét két validált kérdőív, a Bristol Female Lower Urinary Tract Symptoms (BFLUTS) és az International Prostate Score System (IPSS) segítségével mérték fel. A beavatkozást megelőző és az utolsó posztoperatív vizsgálat során kapott BFLUTS- és IPSS-értékek összehasonlítása során a vizeletürítési funkcióra vonatkozó pontszámok szignifikánsan magasabbak voltak a mútét előttiekhez képest mind az idegkímélő, mind a nem idegkímélő technikával operált betegek esetén. Idegkímélő beavatkozást követően ugyanakkor a betegek vizeletürítésre vonatkozó pontszámai szignifikánsan alacsonyabbak voltak, mint a nem idegkímélő mütétek után [18].

Klinikánk endometriosis-munkacsoportja 2009 és 2012 között 50 szegmentális bélreszekciót végzett vastagbelet érintő, mélyen infiltráló endometriosis miatt. Az operált betegek közül hat esetben (12\%) lépett fel átmeneti húgyhólyag-diszfunkció, amely minden esetben 7 napon belül maradéktalanul gyógyult. Krónikus vizeletretenció egy esetben sem fordult elő [19] (2. táblázat).
Bonneau és mtsai összefoglaló tanulmányukban a betegek urodinámiás vizsgálati eredményeit hasonlították össze. A mütétet megelőzően körülbelül a betegek felében figyeltek meg eltéréseket az urodinámiás vizsgálati leletekben. A mütéteket követően a betegek átlag 4,8\%ában (1,4-29,9\%) észleltek de novo húgyhólyag-diszfunkciót. Az operált betegek átlagosan 4,6\%-ában (0-14,7\%) alakult ki tartós húgyhólyag-diszfunkció. Idegkímélő mútéti technika alkalmazása csökkentette a posztoperatív húgyhólyag-diszfunkció kialakulásának valószínüségét [22].

Kavallaris és mtsai összefoglaló közleményében az összes vizsgált beteg egyoldali sacrouterinszalag-reszekción esett át. Az alkalmazott idegkímélő mútéti technikának köszönhetően posztoperatív húgyhólyag-diszfunkció nem jelentkezett, önkatéterezésre egy esetben sem volt szükség [23].

\section{Megbeszélés}

A mélyen infiltráló endometriosis kezelésének célja a krónikus, illetve catamenialis fájdalom gyógyítása és a teherbe esés valószínűségének növelése $[2,9]$. A korábban széles körben alkalmazott klasszikus, Redwine szerinti radikális mútétek azonban terápiás hatékonyságuk mellett jelentős posztoperatív szövődményrátával társultak [2, 23]. Ezek közül a legsúlyosabb az akár élethosszig tartó, krónikus, enyhébb esetekben átmeneti húgyhólyag-diszfunkció, amely önkatéterezés szükségességéhez vezet. Emellett orgazmuszavarok és constipatio is gyakrabban jelentkezett a radikális mütéteket követően [2, 23]. Az említett szövődmények gyakrabban fordultak elő kiterjedtebb reszekció szükségessége esetén, így colpectomiát, parametrectomiát és coloanalis anastomosist követően [22].

A szövődmények csökkentésére irányuló több mint egy évtizedes törekvéseknek köszönhetően a kismedencei vegetatív beidegzést ellátó idegfonatok lokalizációjáról egyre több adat áll rendelkezésre. Több, mélyen infiltráló endometriosissal, illetve korai cervicalis carcinomiával foglalkozó munkacsoport tûzte ki célul a posztoperatív szövődmények előfordulási gyakoriságának minimalizálását különböző idegkímélő műtéti technikák kidolgozásával [2, 4, 18, 19, 21, 23].

A mélyen infiltráló endometriosis a laesio lokalizációjától függően urodinámiás eltérésekkel és vizeletürítési panaszokkal is társulhat $[18,22]$. Ballester és munkatársainak megfigyelései szerint a mútéti beavatkozás minden esetben kedvezőtlen hatású a vizeletürítési funkcióra nézve [18]. Ugyanakkor idegkímélő mútéteket követően húgyhólyag-diszfunkció kialakulásával ritkábban kell számolnunk, mint nem idegkímélő beavatkozások után. Az előző csoportban a vizeletretenció előfordulási gyakorisága 0-29\% közötti, míg nem idegkímélő beavatkozásokat követően 19,1-38,5\% [21, 23, 24]. Idegkímélő mútéteket követôen a posztoperatív vizeletretenció a feldolgozott közlemények eredményei alapján minden 
esetben átmeneti jelenség volt, krónikus húgyhólyagdiszfunkció egy esetben sem fordult elő. Önkatéterezésre szoruló betegekben a katéterhasználat időtartama szignifikánsan alacsonyabb volt idegkímélő beavatkozások után, mint nem idegkímélő mútéteket követően [2, $4,19,21,23]$. Urodinámiás eltérések is alacsonyabb arányban voltak megfigyelhetőek az idegek vizualizációja és megörzése esetén, mint klasszikus mútétek után [22].

Mindezek alapján megállapítható, hogy bár a posztoperatív szakban felléphet átmeneti vizeletretenció, és a betegek átmenetileg önkatéterezésre szorulhatnak, idegkímélő mútéteket követően ennek előfordulási valószínúsége jelentôsen alacsonyabb, és a katéterhasználat szükségességének időtartama is rövidebb $[2,4,19,21$, 23]. Spontán regresszióra, a húgyhólyagfunkció javulására idegkímélő mútéteket követően nagyobb az esély, mint radikálisabb beavatkozások után [18]. Colorectalis, illetve a szexuális funkciót érintő szövődmények is ritkábban fordultak elő idegkímélő, mint nem idegkíméló beavatkozások után [4].

A klasszikus, radikális beavatkozásokhoz képest az idegek vizualizációja és lehetőség szerinti megőrzése tehát mind a húgyhólyag-, mind a szexuális és a székletürítési funkció szempontjából kedvező hatású $[2,4,18,19,21$, $22,23]$. Idegkímélő mútéteket követően ritkábban jelentkeznek posztoperatív szövődmények, ha mégis, azok kevésbé súlyosak és spontán gyógyhajlamuk jelentősen kedvezőbb, mint a nem idegkímélő, radikális beavatkozások szövődményei. Emellett az idegkímélő beavatkozások terápiás hatékonysága megegyezik a radikális mútétek esetén tapasztaltakkal $[2,7,9,14,21]$.

Kritikaként felmerülhet, hogy az idegkímélő beavatkozások időigényesebbek lehetnek. Mélyen infiltráló endometriosissal foglalkozó, idegkímélő mútéti technikát gyakorló munkacsoportok azonban ezt cáfolták. Megfigyeléseik szerint idegkímélő mútéteik rövidebb ideig tartottak és kevesebb vérvesztéssel is jártak, mint a klasszikus, radikális beavatkozások $[4,21]$.

A jövőben nagy esetszámú, prospektív, randomizált tanulmányokra van szükség, amelyek pontosabb képet adhatnak az egyes módszerek hatékonyságáról. Addig is a mélyen infiltráló endometriosis kezelésére specializálódott centrumokban javasolt a módszerek elsajátítása és a gyakorlatban történő alkalmazása.

Anyagi támogatás: A közlemény megírása, illetve az ezzel kapcsolatban elvégzett kutatómunka anyagi támogatásban nem részesült.

Szerzői munkamegosztás: B. A., R. J.: Hipotézisek kidolgozása. B. A., L. P.: Mútétek elvégzése. B. A., R. J., Cs. N., B. R., J. J. G.: Mütéti eredmények feldolgozása, posztoperatív betegkövetés.

Érdekeltségek: A szerző́knek nincsenek érdekeltségeik.

\section{Irodalom}

[1] Beltran, M. A., Tapia, Q. T., Araos, H. F., et al.: Ileal endometriosis as a cause of intestinal obstruction. Report of two cases. Rev. Med. Chil., 2006, 134(4), 485-490.

[2] Kavallaris, A., Banz, C., Chalvatzas, N., et al.: Laparoscopic nerve-sparing surgery of deep infiltrating endometriosis: description of the technique and patients' outcome. Arch. Gynecol. Obstet., 2011, 284(1), 131-135.

[3] Cornillie, F. J., Oosterlynck, D., Lauweryns, J. M., et al.: Deeply infiltrating pelvic endometriosis: histology and clinical significance. Fertil. Steril., 1990, 53(6), 978-983.

[4] Milingos, S., Protopapas, A., Drakakis, P., et al.: Laparoscopic management of patients with endometriosis and chronic pelvic pain. Ann. N.Y. Acad. Sci., 2003, 997, 269-273.

[5] Ceccaroni, M., Clarizia, R., Bruni, F., et al.: Nerve-sparing laparoscopic eradication of deep endometriosis with segmental rectal and parametrial resection: the Negrar method. A single-center, prospective, clinical trial. Surg. Endosc., 2012, 26(7), 20292045.

[6] Ceccaroni, M., Clarizia, R., Alboni, C., et al.: Laparoscopic nerve-sparing transperitoneal approach for endometriosis infiltrating the pelvic wall and somatic nerves: anatomical considerations and surgical technique. Surg. Radiol. Anat., 2010, 32(6), 601-604.

[7] Kavallaris, A., Köbler, C., Kühne-Heid, R., et al.: Histopathological extent of rectal invasion by rectovaginal endometriosis. Hum. Reprod., 2003, 18(6), 1323-1327.

[8] Houtmeyers, P., Ceelen, W., Gillardin, J. M., et al.: Surgery for gastrointestinal endometriosis: indications and results. Acta Chir. Belg., 2006, 106(4), 413-416.

[9] Darai, E., Thomassin, I., Barranger, E., et al.: Feasibility and clinical outcome of laparoscopic colorectal resection for endometriosis. Am. J. Obstet. Gynecol., 2005, 192(2), 394-400.

[10] Simoens, S., Dunselman, G., Dirksen, C., et al.: The burden of endometriosis: costs and quality of life of women with endometriosis and treated in referral centres. Hum. Reprod., 2012, 27(5), 1292-1299.

[11] De Lapasse, C., Renouvel, F., Chis, C., et al.: Urinary functional and urodynamic preoperative evaluation of patients with deep pelvic surgical endometriosis: about 12 cases. Gynecol. Obstet. Fertil., 2008, 36(3), 272-277.

[12] Ceccaroni, M., Clarizia, R., Roviglione, G., et al.: Neuro-anatomy of the posterior parametrium and surgical considerations for a nerve-sparing approach in radical pelvic surgery. Surg. Endosc., 2013, 27(11), 4386-4394.

[13] Abbott, J., Hawe, J., Hunter, D., et al.: Laparoscopic excision of endometriosis: a randomized, placebo-controlled trial. Fertil. Steril., 2004, 82(4), 878-884.

[14] Garry, R., Clayton, R., Hawe, J.: The effect of endometriosis and its radical laparoscopic excision on quality of life indicators. BJOG, 2000, 107(1), 44-54.

[15] Redwine, D. B., Koning, M., Sharpe, D. R.: Laparoscopically assisted transvaginal segmental resection of the rectosigmoid colon for endometriosis. Fertil. Steril., 1996, 65(1), 193-197.

[16] Thomassin, I., Bazot, M., Detchev, R., et al.: Symptoms before and after surgical removal of colorectal endometriosis that are assessed by magnetic resonance imaging and rectal endoscopic sonography. Am. J. Obstet. Gynecol., 2004, 190(5), 1264-1271.

[17] Fedele, L., Bianchi, S., Zanconato, G., et al.: Long-term follow-up after conservative surgery for rectovaginal endometriosis. Am. J. Obstet. Gynecol., 2004, 190(4), 1020-1024.

[18] Ballester, M., Chereau, E., Dubernard, G., et al.: Urinary dysfunc tion after colorectal resection for endometriosis: results of a prospective randomized trial comparing laparoscopy to open surgery. Am. J. Obstet. Gynecol., 2011, 204(4), 303.el-303.e6. 
[19] Bokor, A., Brubel, R., Lukovich, P., et al.: Experience with multidisciplinary laparoscopic surgery in patients with deep infiltrating colorectal endometriosis. [Mélyen infiltráló colorectalis endometriosis miatt végzett multidiszciplináris laparoszkópos mútétek során szerzett tapasztalataink.] Orv. Hetil., 2014, 155(5), 182-186. [Hungarian]

[20] Volpi, E., Ferrero, A., Sismondi, P.: Laparoscopic identification of pelvic nerves in patients with deep infiltrating endometriosis. Surg. Endosc., 2004, 18(7), 1109-1112.

[21] Possover, M., Quakernack, J., Chiantera, V.: The LANN technique to reduce postoperative functional morbidity in laparoscopic radical pelvic surgery. J. Am. Coll. Surg., 2005, 201(6), 913-917.

[22] Bonneau, C., Zilberman, S., Ballester, M., et al.: Incidence of preand postoperative urinary dysfunction associated with deep infiltrating endometriosis: relevance of urodynamic tests and therapeutic implications. Minerva Ginecol., 2013, 65(4), 385-405.
[23] Kavallaris, A., Mebes, I., Evagyelinos, D., et al.: Follow-up of dysfunctional bladder and rectum after surgery of a deep infiltrating rectovaginal endometriosis. Arch. Gynecol. Obstet., 2011, $283(5)$ 1021-1026.

[24] Dubernard, G., Rouzier, R., David-Montefiore, E., et al.: Urinary complications after surgery for posterior deep infiltrating endometriosis are related to the extent of dissection and to uterosacral ligaments resection. J. Minim. Invasive Gynecol., 2008, 15(2), 235-240.

\section{MEGHÍVó}

\section{A Szent János Kórház és Észak-budai Egyesített Kórházak Tudományos Bizottsága}

tisztelettel meghívja az érdeklődőket a következő tudományos ülésére, amelyet az I. Belgyógyászati és Gasztroenterológiai Osztály

a Magyar Gasztroenterológiai Társasággal

és a Magyar Ultrahang Társasággal közösen rendez.

Időpont: 2015. december 10. (csütörtök) 14 óra

Helyszín: Szent János Kórház Auditóriuma - 1125 Budapest, Diós árok 1-3.

Téma: „Aktualitások a gasztroenterológiában” - Újdonságok, érdekességek, esetek

Üléselnök: Prof. Dr. Nemesánszky Elemér és Dr. Székely György

\section{Program:}

Dr. Szilvás Ágnes: Szürhető-e a vastagbélrák?

15 perc

Dr. Pusztay Margit:

A nyomok a májhoz vezetnek: májbetegségek extrahepatikus szövődményei

15 perc

Dr. Horváth Gábor:

Korszakváltás a HCV terápiában: Új direkt ható antivirális szerek

15 perc

Dr. Kovács Márta:

Újdonságok a kapszula endoszkópos diagnosztikában

15 perc

Dr. Darvas Emília:

Meglepő fordulat: a diagnosztikus gondolkodás változása kapszula

endoszkópia során - esetbemutatás

10 perc

Dr. Székely György: Széklet microbióta: Genetikai önéletrajz?

$$
\text { VITA - BÜFÉ }
$$

Minden érdeklődőt szeretettel várunk.

A Semmelweis Egyetem által akkreditált rendezvény. 